\title{
Does Animation Services Really Matter? Place of Animation Services in the Perceived Quality-Overall Satisfaction Model
}

\author{
Oğuz Türkay \\ Sakarya University, Faculty of Tourism \\ Abdulmenaf Korkutata \\ Canakkale Onsekiz Mart University, Faculty of Sport Sciences \\ Özer Y1lmaz \\ Bandırma Onyedi Eylul University, Faculty of Omer Seyfettin Applied Sciences
}

\begin{abstract}
In this study, the effect of the quality of the animation service to the perceived quality of a resort hotel and, thus, overall customer satisfaction within hotel service departments is addressed comparatively. The perceived quality of animation services (PQAS) has been measured by the behaviour of workers, the sufficiency of service's content, knowledge and experiences of workers, and the factors of the program. Surveys were used by quota sampling to tourists who were in resort hotels in Antalya, Turkey, wherein 1189 usable feedbacks were obtained. The model, which was tested using SmartPLS, was found significant. It has been determined that the PQAS significantly affected the perception of the quality of the hotel even though it is lesser than the perceived quality of other departments. The perception of the quality puts forward a significant amount of overall customer satisfaction. The results were analyzed in customer satisfaction theory and experiential marketing fields.
\end{abstract}

Key words: Animation services, service quality, overall customer satisfaction, resort hotels

JEL Classifications: L83, M31, Z33

\section{Introduction}

The importance of animation services in resort hotels shows interdependency between industrialization and increasing strength of sejour tourism, which depends on relaxation and fun. Animation services are embraced as activities that heat up the resort hotel and destination and create an emotional encouragement and a charming atmosphere (Sotiriadis, 2014). With that, the presence, the quality, and the suitability to the customers of animation services can be crucial for resort hotels as it can be an important charm, designate the level of satisfaction of a customer, and influence the possibility of re-visitation of the resort (Mikulic \& Prebezac, 2011). Correspondingly, it is obvious that considering the animation services as a competition advantage, trying to develop these services is extensively important for the success of hotels and destinations (Meng et al., 2008). For that, the features of an animation program that charms the tourist and its reflections to perceived quality and overall satisfactions are showing up as subjects to be researched. Despite its importance, attention should be drawn into the rarity of pieces of work that states the significance of animation works for resort hotels 
(Mikulic \& Prebezac, 2011).

PQAS was exclusively approached in sea-sun-sand hotels because the accommodation period is longer, and thus, the animation activities are presented as an additional service. The roots of animation services stand to the practices of the hotels, which are situated in Spain's and France's Mediterranean shores, and it is considered as a widespread set of activities in resort hotels even today. The contents of these activities may differ in terms of different areas or enterprises. The enterprises shape their presentations by the preferences of their customers and in order to ensure a positive perception of service quality and strong customer satisfaction. According to the current studies in customer satisfaction theory, it was needed to identify the more important attributes so that managers may invest resources to these, and customer satisfaction may be increased (Busacca \& Padula, 2005). As a unique resource of customer satisfaction, the quality of animation services must be tested and how the perception on the quality level of offered animation services were plays a role in customer satisfaction.

The perception of quality and the satisfaction of customers are crucial because customer satisfaction leads to increase of income, customer loyalty, and thereby leads to long-term profit and advantage among the rivals (Kandampully \& Suhartanto, 2000). The subject of customer satisfaction is more crucial for resort hotels because these kinds of hotels are deeply affected by the factors that they cannot control such as climate and economic inconsistency (Knutson et al., 2004). This converts the resort hotel business to become a very competitive environment, and this competitiveness leads to profit margin to be deleted, sensitivity against the customer to be depleted, profits to be negatively affected, and the bonding with customers to be broken down. Knutson et al. (2004) also point out the fact that studies on customer satisfaction are insufficient in resort hotels. On the other hand, the works show that senses of quality about some specific services are the elements of creating customer satisfaction. However, the fact that these elements are dependent on time should not be forgotten. There is no sufficient survey about the contribution of new vacation options and animation services as additional services of hotels to the customer satisfaction (Albayrak et al., 2016).

Customer satisfaction was discussed frequently by the effects of SERVQUAL dimensions. Mattila \& O'Neill (2003) went beyond SERVQUAL dimensions even though it was traditionally accepted and spread, testing room prices and the occupancy rates, which shows that room price is a significant factor in detecting customer satisfaction. That is why there is no clearance about the factors on the subjects of some matters that are accepted as the determinants of final satisfactions or the perceived quality. Also, there is already an uncertainty that depends on the results of various studies about expectations that state the satisfaction (Yuksel \& Yuksel, 2001). This uncertainty necessitates thinking broadly and caring about possible effects of all service options while questioning the factors of customer satisfactions. For this instance, it would be fair to handle the animation service whose importance is gradually growing as a factor that should be graded in instances of the quality of the resort hotel and studies about customer satisfaction.

In this study, instead of questioning psychological, physical, and social elements in a broad aspect, as determiners of the quality of services and customer satisfaction in resort hotels, the PQAS is approached directly, and the role of this perception in perceived qualityoverall satisfaction model is measured by comparing it with traditional services.

\section{Literature Review}




\subsection{The role of animation quality in hotel experiences}

The products of animation as leisure activities are the activities that make the time left from eating, drinking, and planned tour activities meaningful. These activities shape with the principle of volunteerism, provide the participants one-on-one interactions, can depend on physical action and mental efforts, and put forward the effects of renewal, refreshment, and support to self-confidence for a person. Most importantly, they give birth to the rhythm of having fun, relaxation, and easing while creating the socialization process. Animation, states the leisure and recreation activities, is a hotel service especially found and spread in Europe's resort hotels, which contain entertainment activities, leisure time activities, sports, and fitness. Hotels maintain animation services free of charge and with the aim of pleasing the customers more. Costa et al. (2004) state that the recreation and animation activities are mainly composed of sport games, dancing and walking activities, cultural activities, adventure sports, and outdoor events. These activities develop feelings of creativity, social connection, physical dynamism, adventure, and self-exploration. Such positive contributions to oneself show that it should be understood as these activities are perceived positively for the hotels as well.

\subsection{The Interaction between PQAS-Perceived hotel quality-Overall customer satisfactions}

Some various examples can be given as a proof on the subject of animation being effective to perception of hotel's quality. Uysal (2003) draws the attention to the possibility of a more positive perception for all vacation processes, while animation services create an actualization effect. Knutson et al. (2004) emphasized that the family activities such as golf courses, outdoor activities, and weekend events were crucial satisfaction factors even though it might be a business trip. According to Sotiriadis (2014), the quality of the animation services is an important factor for explaining the general satisfaction because (a) the participation level of tourists is very high, (b) the participation to animation widens the portfolio of customers, (c) it increases the number of repeat guests, (d) it increases the dependence of customers, and (e) it increases the suggestions from mouth to mouth.

The quality of a hotel is taken as a conclusion that has been found by comparing the expectations of customers and the performance that they receive at the end of the vacation (Caruana, 2002). In relation to this, Weiermair \& Fuchs (1999) handled the effects of animation services as factors whose importance came into being with the extents of varying customer preferences and anticipations. Whereas Costa et al. (2004) state that these services are the most powerful factors that produce inner motivation intended for hotels. Johann \& Anastassova (2014) claim that animation events and entertainment organizations are regarded as important determiners of quality and satisfaction by the eyes of Polish customers in Bulgarian hotels; with these events, the hotel would be received as of high quality, and without them, the complaints from customers would increase. Demir \& Demir (2015) empirically revealed that the animation strengthens the bond between a customer and the hotel and draws a great amount of charm to families with children especially. This importance is constituted by a bond between the PQAS and the perceived service quality taken by the hotel's overall services.

Hypothesis 1: The PQAS affects the level of perceived quality of the hotel positively. 
Even though it is limited, current literature refers to a specific relationship between PQAS and hotel's perceived quality. But this relationship should be considered in comparison with the effects of other departments. It can be expected that Front Office, Housekeeping, and Food \& Beverage, which are the operational departments, would deeply affect the perceived quality and satisfaction in hotels. Front Office takes the role of a bridge between the customer and the rest of the hotel or the role of a brain and designates the image of the hotel in the customers' eyes (Hai-yan \& Baum, 2006). Housekeeping is seen as the most important department for the tourists and the most effective on satisfaction of customers according to Kandampully \& Suhartanto's (2003) findings. On the other hand, the department of Food \& Beverage is proven and stated to have an effect on customers (Pizam \& Ellis, 1999; Kandampully \& Suhartanto, 2003).

Hypothesis 2: The perceived quality of other departments affects the level of perceived quality of the hotel positively.

Customer satisfaction as an output, which is reached after consuming the service process (Fallon \& Schofield, 2004), is embraced as comparison between a customer's anticipated service and received performance and as a final judgment when in the state of meeting the expectations (Oliver, 1980). The perception of quality or performance in some fields in which a customer created anticipation can be approached as a premise to customer satisfaction at hotels. Sureshchandar et al. (2002) state that quality and customer satisfaction are connected closely to each other, yet separate. It can be said that there is a wide field of inspection in literature about quality and factors of satisfaction. Many works, which are in content of expectation-disconfirmation theory, testing physical features, empathy, responsiveness, and trust, which are the pioneers of customer satisfaction, on grounds of Parasuraman et al.'s (1985) SERVQUAL dimensions. Oh (1999), in his work about hotel consumers, proves that service quality affects the consumer's satisfaction.

Hypothesis 3: The perceived quality of the hotel affects the level of overall satisfaction positively.

\section{Methodology}

In this study, it is aimed to clarify the role of PQAS in terms of the perceived quality of the hotel and creating customer satisfaction in five-star resort hotels. With this aim, the model, which is established for determining the effects of the PQAS and the perceived quality of services about the other departments (Front Office, Housekeeping, and F\&B) to the perceived quality of hotel services and the effects of perceived quality of hotel services to overall satisfaction, is being questioned in the context of SEM.

\subsection{Measures}

Some important determiners for PQAS should be ranked. Animators play a key role to meet the expectations of tourists from animation services (Sotiriadis, 2014). For the efficiency of recreational activities, there is a need for qualified personnel for directing, training, and controlling the tourist in nearby places such as sport fields, pools, saunas, gym, and fitness fields. In addition, the content of animation activities and which of these contents was liked 
more by the tourists is the key dimension for understanding the effect of the animation services on tourists (Shportko, 2012). Facilities, equipment, and atmosphere (surrounding, participants, and location) are some other options that their suitability may determine the level of PQAS (Sotiriadis, 2014). In this study, instead of the quality determiners that are handled by the broad perspective, the subject is being reviewed on a scale that covers a measureable scope. According to that, the elements that identify the quality that perceived from the animation services can be inspected in five titles: (a) the manners of the workers, (b) the sufficiency of the content of services, (c) the sufficiency of the materials and surroundings, (d) the knowledge and experience of the workers, and (e) the extent of the program. Items have been developed from the studies of Taylor et al. (1993) that has questioned recreation service quality by focusing on leisure activity firms; Mikulic \& Prebezac (2011) that processed the subject by measuring the variety of programs, facility, and equipment, number of participants, staff competence, and staff politeness.

The rate of "being satisfied" is questioned for measuring the perception of quality on other departments. The expressions such as "I am satisfied with the Front-Office services", "I am satisfied with the Housekeeping services", and "I am satisfied with the Food \& Beverage services" have been used. A similar way has been used for measuring the general perception of quality of hotel services. For this, the way of directly voting the lower dimensions of SERVQUAL scales has been followed. The expressions such as, "The physical features are sufficient.", "I feel safe.", and "The staff is always ready and willing.", "The staff is able to understand and answer the customer's needs.", "The promised services and the presented services are consistent" have been used.

Measuring overall satisfaction, the logic behind the relation between the values of satisfaction measurement and the perception of hotel's quality should be perfectly understood. It is accepted by many researchers that the measurement of service quality does not represent the final satisfaction (Costa et al., 2004; Parasuraman et al. 1988). It is indicated that there is a difference between overall satisfaction and the satisfaction about the features does explain the total but is not the ultimate premise (Petrick \& Backman, 2002). While measuring the subject, its suitability to the satisfaction of the customer and judgmental values should be taken into consideration (Noe \& Uysal, 1997). In overall satisfaction measurement, the ability to measure with only one expression has been put forward by studies (Cronin and Taylor, 1992). Sivadas \& Baker-Prewitt (2000) measured the quality of service with SERVQUAL and the satisfaction of customer with single expression scales such as "Which is your general degree of satisfaction?". With a similar method, Caruana et al. (2000) measure the overall satisfaction with three items. In this study, the overall satisfaction is measured by these two expressions; "I think I have made a correct decision coming here" and "I am overall content with the quality of services". All expressions scaled in ways such as (1) strongly disagree-(5) strongly agree.

\subsection{Sample and procedure}

For stating the sample, an approach based on the aim and quota sampling methods are followed. Firstly, because the study would only include resort hotels, it was thought to limit it to only Antalya City. Antalya is the most popular coastal destination of Turkey. 14.7 million tourists in 2014 and 14.5 million tourists in 2015 stayed in tourism facilities in Antalya. Those numbers compose the $36 \%$ in 2014 and the $33 \%$ in 2015 of the overall tourism in Turkey. The percentages become $51 \%$ for 2014 and $48 \%$ for 2015 when only the foreign tourists are taken 
into consideration (MCT, 2016). It can be observed that Antalya is treated as an example in works that study the animation services in resort hotels (Albayrak et al., 2016).

On the other hand, it was decided to make the research in four-star or five-star hotels because these kinds of facilities are shining out as the groups of facilities, which are presenting a broad service of animation with a specific standard and quality. By year 2014, 305 five-star and 237 four-star hotels are present in Antalya (APDCT, 2015).

In this research, because it was based upon understanding the perception of the tourist, it was desired to exclude some unwanted effects. For this, some effects have been neutralized, such as (a) effects based on a specific hotel by reaching others who are staying in different hotels, (b) effects based on surroundings by reaching out to other hotels in different places, and (c) effects based on nationalities by reaching other tourists who are from various countries. With stated contents, for Antalya, samples from Kemer, Belek and Alanya have been chosen in which there are many great accommodation facilities. The facilities have been chosen randomly with the help of the list of settled hotels in those places, and they have been called to help by taking an appointment. Another random choice has been added to the list, instead of the ones that did not agree to work with this project. The subject of reaching the determined nationalities was taken into consideration while choosing the facilities. It has especially been tried to reach the tourists that are German, Russian, English, and Turkish because German, Russian, and English markets are the first three markets in the scene (MCT, 2016). With these limitations, the data from 1189 tourists, which can be analyzed, are obtained.

To translate the scale into given languages, help has been sought from faculty members who are professionals in their fields and giving language courses. With the translateretranslate technique, it has been shaped to its final form after the control of faculty members who are studying in the field of business management.

\section{Results and Discussion}

\subsection{Characteristics of respondents}

Table 1 shows features of participants; $56.9 \%$ of the participants are women. When observed through the age factor, $22.1 \%$ of the participants are 25 years or younger, $37 \%$ are between the ages of 26 and 34, 22.3\% are between 35 and 44, 12.4\% are between 45 and 54, and finally, $6.2 \%$ are them are 55 or older. When it is observed by their status of education, it can be seen that $8.7 \%$ are graduates from primary school, $32.5 \%$ are from high school or equal, $27.9 \%$ are from upper secondary education, $25.9 \%$ have a bachelor's degree, and $5.4 \%$ are graduates with post-graduate or master's degree. The features that are indicated are compatible for the structure of the demand for resort hotels.

Table 1

Defining Variables

\begin{tabular}{|l|c|c|l|c|c|}
\hline Variable & Frequency & $(\%)$ & Variable & \multicolumn{1}{|c|}{ Frequency } & $(\%)$ \\
\hline Gender & 513 & 43.1 & Yes & 384 & 32.3 \\
\hline Male & 513 esitation status & \multicolumn{3}{|c|}{} \\
\hline
\end{tabular}




\begin{tabular}{|c|c|c|c|c|c|}
\hline Female & 676 & 56.9 & No & 805 & 67.7 \\
\hline \multicolumn{3}{|l|}{ Age } & \multicolumn{3}{|c|}{ Who the person came with } \\
\hline 25 and under & 263 & 22.1 & Alone & 245 & 20.6 \\
\hline $26-34$ & 440 & 37.0 & With wife-/husband & 218 & 18.3 \\
\hline $35-44$ & 265 & 22.3 & With family & 361 & 30.4 \\
\hline $45-54$ & 147 & 12.4 & With friend(s) & 282 & 23.7 \\
\hline 55 and over & 74 & 6.2 & Other & 83 & 7.0 \\
\hline \multicolumn{3}{|l|}{ Graduation } & \multicolumn{3}{|l|}{ Duration of stay } \\
\hline Primary school & 104 & 8.7 & Between 1 and 7 days & 423 & 35.6 \\
\hline High school & 387 & 32.5 & $8-14$ days & 590 & 49.6 \\
\hline Upper secondary & 326 & 27.4 & 15-21 days & 144 & 12.1 \\
\hline Bachelor's & 308 & 25.9 & $22-30$ days & 26 & 2.2 \\
\hline $\begin{array}{l}\text { Post-graduate \& } \\
\text { Master's }\end{array}$ & 64 & 5.4 & 31 days and over & 6 & .5 \\
\hline \multicolumn{3}{|l|}{ Nationality } & \multicolumn{3}{|l|}{ Purpose of visit } \\
\hline Turkish & 279 & 23.5 & Entertainment & 736 & 61.9 \\
\hline German & 339 & 28.5 & Health & 195 & 16.4 \\
\hline English & 315 & 26.5 & Sport & 157 & 13.2 \\
\hline Russian & 251 & 21.1 & Adventure & 277 & 23.3 \\
\hline \multirow[t]{4}{*}{ Other } & 5 & .4 & Culture & 153 & 12.9 \\
\hline & & & Business & 49 & 4.1 \\
\hline & & & Visitation of friends & 42 & 3.5 \\
\hline & & & Other & 26 & 2.2 \\
\hline
\end{tabular}

Source: Authors

The nationality of the participants is $28.5 \%$ German, 26.5\% English, 23.5\% Turkish, $21.1 \%$ Russian, and the remaining $0.4 \%$ of the participants are citizens from any other country. When re-visitation status is observed, $32.3 \%$ of the customers went to the exact same facility before and $67.7 \%$ of them did not. When the subject of who the customer came with is taken into consideration, it is seen that $20.6 \%$ of them came alone, $18.3 \%$ came with their wives or husbands, $30.4 \%$ of them came with their families (wife/husband and kids), $23.7 \%$ came with their friends, and $7 \%$ came with the others. Duration of visit is spread around participants as follows; $35.6 \%$ are between 1 and 7 days, $49.6 \%$ are between 8 and 14 days, $12.1 \%$ are between 15 and 21 days, $2.2 \%$ are between 22 and 30 days, and the remaining $0.5 \%$ are more than 30 days. The purpose of visitation is ranked as follows; $61.9 \%$ of the participants visited the facilities for entertainment, $23.3 \%$ for adventure, $16.4 \%$ for health, $13.2 \%$ for sports, $12.9 \%$ for cultural activities, $4.1 \%$ for business, $3.5 \%$ for visitation of friends, and $2.2 \%$ for other reasons.

\subsection{Preliminary analyses}

The data were screened for univariate outliers. It showed that 33 data (\% 0.056) are empty. Also three out-of-range values, due to administrative errors, were identified and recoded as missing data. The missing data were estimated with the expectationmaximization (EM) algorithm. The EM algorithm estimates the parameters of a model iteratively, starting from some initial guess. Each iteration consists of an expectation (E) step, which finds the distribution for the unobserved variables, given the known values of the observed variables and the current estimate of the parameters, and a maximization (M) step, which re-estimates the parameters to those with maximum likelihood, under the assumption that the distribution found in the R step is correct (Neal \& Hinton, 1998). 
The study hypotheses were tested using the structural equation modeling (SEM). Despite the assumption that measurement of the observed variables of other analysis techniques does not involve errors, SEM also calculates and incorporates measurement errors into the model test. In addition, the SEM provides a set of model fit indexes to determine whether the causal relationships covered by the proposed structural model are supported by the data (Park et al., 2014).

To select the estimation method of SEM, first, the normality was tested. The test was performed using the mean score regarding the structures. It has been seen that all variables have non-normal distribution (Table 2). For this reason, the partial least square algorithm (PLS) was used to test the model. PLS is a modelling approach to SEM with no assumptions about distribution (Esposito Vinzi et al. 2010). In spite of some limitations, PLS is a useful SEM applied research project especially when the data are limited participants and that the data distribution is skewed (Wong, 2013).

Table 2

Normality Tests of Items

\begin{tabular}{|l|c|c|c|c|c|c|}
\hline \multicolumn{1}{|c|}{ Structure } & Mean & $\begin{array}{l}\text { Standard } \\
\text { Deviation }\end{array}$ & Skewness & Kurtosis & $\begin{array}{c}P \text { value of } \\
\text { Kolmogorov } \\
- \text { Smirnov }\end{array}$ & $\begin{array}{c}P \text { value of } \\
\text { Shapiro- } \\
\text { Wilk }\end{array}$ \\
\hline $\begin{array}{l}\text { Materials and } \\
\text { Surroundings }\end{array}$ & 4.39 & 0.63 & -1.087 & 1.601 & 0.000 & 0.000 \\
\hline Staff Politeness & 4.57 & 0.49 & -1.376 & 3.516 & 0.000 & 0.000 \\
\hline Program & 4.48 & 0.55 & -1.068 & 1.734 & 0.000 & 0.000 \\
\hline $\begin{array}{l}\text { Knowledge and } \\
\text { Experience of Staff }\end{array}$ & 4.44 & 0.56 & -0.859 & 0.459 & 0.000 & 0.000 \\
\hline Content of Services & 4.46 & 0.59 & -1.117 & 1.512 & 0.000 & 0.000 \\
\hline $\begin{array}{l}\text { Perceived Quality of Other } \\
\text { Departments }\end{array}$ & 4.26 & 0.79 & -1.259 & 1.612 & 0.000 & 0.000 \\
\hline Perceived Quality of Hotel & 4.48 & 0.47 & -1.212 & 3.106 & 0.000 & 0.000 \\
\hline Overall Satisfaction & 4.42 & 0.58 & -1.301 & 2.378 & 0.000 & 0.000 \\
\hline
\end{tabular}

Source: Authors

Following the two-step approach, we first interpreted the items loadings and proposed the relationships between items and latent constructs. According to the theoretical model, "perceived quality of animation facilities" has five dimensions. The other constructs are composed of a single dimension. The convergent validity of the test was measured with AVE (Average Variance Extracted) scores. According to Fornell \& Larcker (1981), 0.50 or greater values of AVE can be accepted for the convergent validity.

The reliability of the analysis was measured with "composite reliability". Traditionally, "Cronbach's alpha" is used to measure internal consistency reliability in social science researches, but it tends to provide a conservative measurement in PLS-SEM. Prior literature has suggested the use of "Composite Reliability" as a replacement (Wong, 2013). Composite reliability should be 0.7 or higher (Bagozzi \& Yi, 1988). The factor loadings, reliability, and validity scores of the constructs of the analysis (using Smart PLS 2.0) are shown in Table 3.

According to Hulland (1999), items loading value 0.70 or higher are preferred but 0.4 or higher is acceptable in exploratory research. As seen in the Table 3, all items' loadings are above 0.7 except for one item. These loadings are indicated that all latent constructs are compatible with theoretical background. Also, all items' Composite Reliability, AVE, and 
Alpha scores are adequate to perform the PLS-SEM modeling.

Table 3

Factor Loadings, Reliability, and Validity Scores of Constructs

\begin{tabular}{|c|c|c|c|c|c|}
\hline Construct & Item & Loading & AVE & $\begin{array}{l}\text { Composite } \\
\text { Reliability } \\
\end{array}$ & $\begin{array}{c}\text { Cronbach's } \\
\text { Alpha } \\
\end{array}$ \\
\hline \multirow{5}{*}{$\begin{array}{l}\text { Materials and } \\
\text { Surroundings }\end{array}$} & Sufficiency of equipment & 0.819 & \multirow{5}{*}{0.7244} & \multirow{5}{*}{0.9291} & \multirow{5}{*}{0.9039} \\
\hline & Visual attractiveness of stage & 0.889 & & & \\
\hline & Plushness of stage & 0.897 & & & \\
\hline & Suitability of spaces & 0.872 & & & \\
\hline & Suitability of building & 0.772 & & & \\
\hline \multirow[t]{7}{*}{ Staff Politeness } & Visual cleanness & 0.786 & \multirow{7}{*}{0.6642} & \multirow{7}{*}{0.9326} & \multirow{7}{*}{0.9157} \\
\hline & Responsiveness & 0.834 & & & \\
\hline & $\begin{array}{c}\text { Customers' } \\
\text { recommendations } \\
\text { consideration }\end{array}$ & 0.809 & & & \\
\hline & Courteousness & 0.830 & & & \\
\hline & Amiableness & 0.840 & & & \\
\hline & Patience & 0.814 & & & \\
\hline & $\begin{array}{l}\text { Special attention to } \\
\text { customers }\end{array}$ & 0.791 & & & \\
\hline \multirow[t]{5}{*}{ Program } & To be customer driven & 0.839 & \multirow{5}{*}{0.6472} & \multirow{5}{*}{0.9007} & \multirow{5}{*}{0.8608} \\
\hline & $\begin{array}{l}\text { Consideration to the } \\
\text { participants }\end{array}$ & 0.868 & & & \\
\hline & $\begin{array}{l}\text { Beginning into the } \\
\text { announced time }\end{array}$ & 0.837 & & & \\
\hline & $\begin{array}{l}\text { Suitability to time it has } \\
\text { showed }\end{array}$ & 0.827 & & & \\
\hline & $\begin{array}{c}\text { Possibility for active } \\
\text { participation }\end{array}$ & 0.628 & & & \\
\hline \multirow{5}{*}{$\begin{array}{lr}\text { Knowledge } & \text { and } \\
\text { Experience } & \text { of } \\
\text { Staff } & \end{array}$} & Professionalism & 0.840 & \multirow{5}{*}{.7267} & \multirow{5}{*}{0.9300} & \multirow{5}{*}{0.9058} \\
\hline & To cope with problems & 0.874 & & & \\
\hline & $\begin{array}{l}\text { Sufficiency of knowledge on } \\
\text { the facility }\end{array}$ & 0.882 & & & \\
\hline & $\begin{array}{l}\text { Readiness to help the } \\
\text { customers }\end{array}$ & 0.842 & & & \\
\hline & Do the duty well & 0.823 & & & \\
\hline \multirow{5}{*}{$\begin{array}{l}\text { Content of } \\
\text { Services }\end{array}$} & Quality of content & 0.851 & \multirow{5}{*}{0.7665} & \multirow{5}{*}{0.9425} & \multirow{5}{*}{0.9237} \\
\hline & Sufficiency of presentation & 0.888 & & & \\
\hline & Variety & 0.898 & & & \\
\hline & Visuality & 0.884 & & & \\
\hline & $\begin{array}{l}\text { Suitability to the } \\
\text { expectations }\end{array}$ & 0.856 & & & \\
\hline \multirow{5}{*}{$\begin{array}{l}\text { PQAS (second } \\
\text { order) }\end{array}$} & Materials and Surroundings & 0.798 & \multirow{5}{*}{0.5110} & \multirow{5}{*}{0.9600} & \multirow{5}{*}{0.9564} \\
\hline & Staff Politeness & 0.856 & & & \\
\hline & Program & 0.845 & & & \\
\hline & $\begin{array}{c}\text { Knowledge and Experience } \\
\text { of Staff } \\
\end{array}$ & 0.848 & & & \\
\hline & Content of Services & 0.828 & & & \\
\hline \multirow{3}{*}{$\begin{array}{l}\text { Perceived Quality } \\
\text { of Other Dept. }\end{array}$} & $\mathrm{F} / \mathrm{O}$ services & 0.857 & \multirow{3}{*}{0.7816} & \multirow{3}{*}{0.9148} & \\
\hline & $\mathrm{H} / \mathrm{K}$ services & 0.910 & & & 0.8601 \\
\hline & F\&B services & 0.884 & & & \\
\hline Perceived Quality & Physical features & 0.795 & & & \\
\hline of Hotel & To feel in trust & 0.833 & 0.6972 & 0.9415 & 0.9274 \\
\hline & $\begin{array}{l}\text { Responsiveness of hotel } \\
\text { employee }\end{array}$ & 0.852 & 0.0912 & 0.9415 & 0.9214 \\
\hline
\end{tabular}




\begin{tabular}{|c|c|c|c|c|c|}
\hline & Readiness of hotel employee & 0.863 & & & \\
\hline & To get in return for paid & 0.856 & & & \\
\hline & Satisfactory services & 0.847 & & & \\
\hline & Consistent services & 0.797 & & & \\
\hline \multirow[t]{2}{*}{$\begin{array}{l}\text { Overall } \\
\text { Satisfaction }\end{array}$} & $\begin{array}{l}\text { Think that gave the right } \\
\text { decision }\end{array}$ & 0.932 & \multirow{2}{*}{0.8688} & \multirow{2}{*}{0.9298} & \multirow{2}{*}{0.8489} \\
\hline & $\begin{array}{c}\text { Satisfaction from overall } \\
\text { services }\end{array}$ & 0.932 & & & \\
\hline
\end{tabular}

Source: Authors

Notes: Weighting Scheme: Factor Loading Scheme, Iteration: 4; AVE: Average Variance Extracted.

The structural model was tested using SmartPLS 2.0. The path coefficients, $t$ values and $\mathrm{R}$ square results of the analysis are shown in Table 4.

Table 4

Path Coefficients, $t$ Values and $R^{2}$ Results of the Model

\begin{tabular}{lccc}
\hline Paths & Coefficients & $t$ value & $R^{2}$ \\
\hline PQAS $\rightarrow$ Perceived Quality of Hotel & $0.222^{*}$ & 2.338 & 0.630 \\
Per. Q. of Other Dept. $\rightarrow$ Perceived Quality of Hotel & $0.665^{* *}$ & 8.038 \\
Perceived Quality of Hotel $\rightarrow$ Overall Satisfaction & $0.557^{* *}$ & 5.668 & 0.311 \\
\hline
\end{tabular}

Source: Authors

Notes: Path Weighting Scheme, Bootstrapping samples: 1000, cases: 100 ; * indicates $\mathrm{p}<0.05$, ** indicates $p<0.01$.

The estimated coefficients and $t$ values given in Table 4 show that all three paths of the model are statistically significant. The first hypothesis of the study is concerning a positive relationship between PQAS and perceived quality of hotel. This hypothesis was supported as PQAS was significantly related to the perceived quality of the hotel $(\beta=0.22, t=2.338, p<$ $0.05)$. The second hypothesis predicts a positive relationship between perceived quality of other departments and perceived quality of hotel was also supported $(\beta=0.665, t=8.038, p<$ 0.01 ). Additionally, it has been seen that $63 \%$ changes occurring of perceived quality of hotel was explained by PQAS and perceived quality of other departments.

Hypothesis 3 states a positive relationship between the perceived quality of the hotel and overall satisfaction. This hypothesis was also accepted according to the test results $(\beta=0.557$, $t=5.668, p<0.01)$. The overall satisfaction was significantly affected by the perceived quality of the hotel. Also, 31\% changes of the overall satisfaction were explained by the perceived quality of the hotel. The results of hypothesis tests are summarized in Figure 1. 
Figure 1

\section{Model Summary}

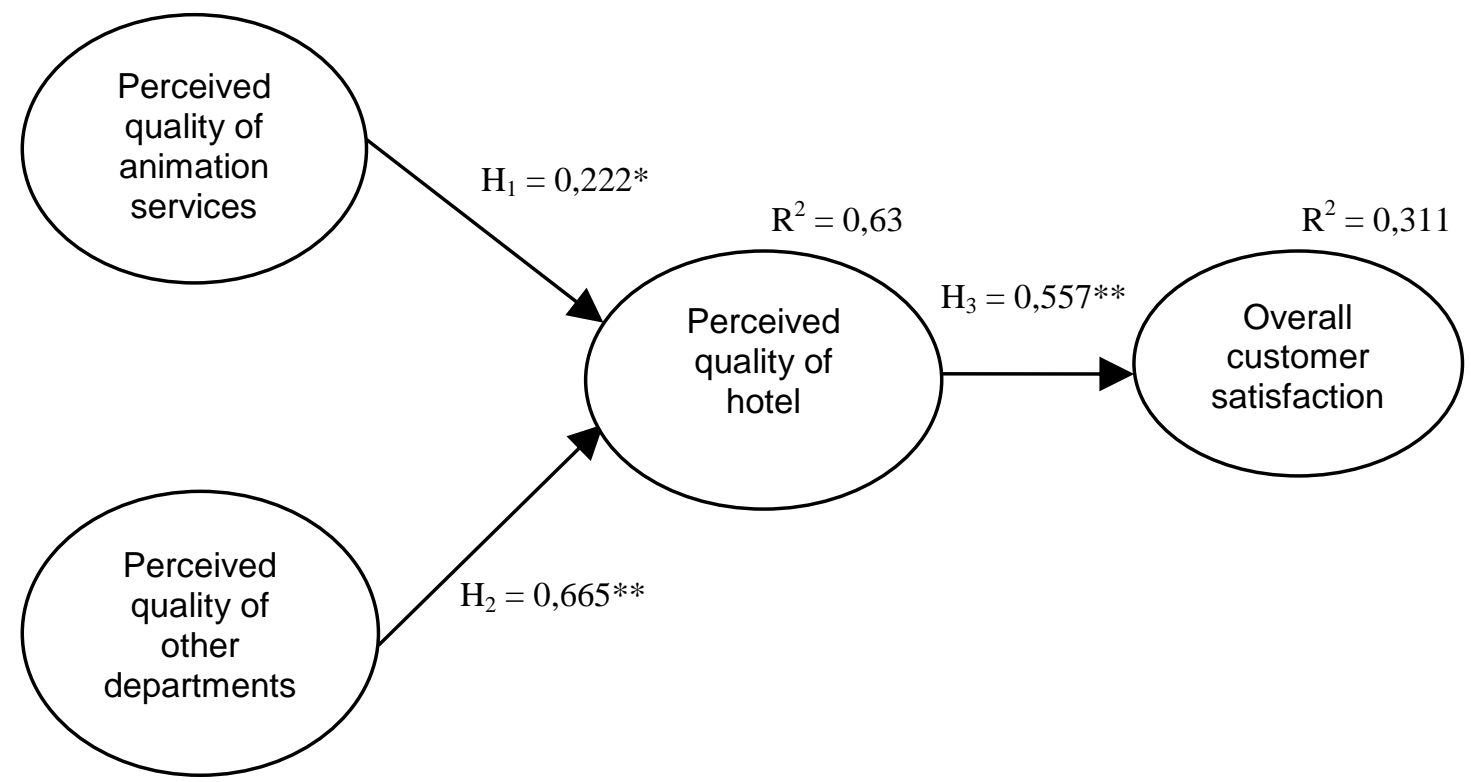

Source: Authors

Notes: $*$ indicates $p<0.05, * *$ indicates $p<0.01$

\subsection{Discussion}

Animation is a component of the tourism and hotel products that consist of an unknown percentage of experiential dimensions and technical and functional dimensions of services. Those services are included in the vacation package and do not allow for a 'value-for-price' evaluation process. Researchers agree that tourism is a totality of experiences rather than a set of services. Animation in resort hotels can be expected in this fashion as a component of the total travel experience, which creates the proper socio-psychological environment (Costa et al., 2004).

To measure the perceived quality of animation services, validation and reliability of related elements, which has been talked about before, are put forward: (a) the politeness of the staff, (b) the sufficiency of activity's content, (c) the sufficiency of material and surroundings, (d) the knowledge and experience of the staff, and (e) the perception of the program's dimensions. PQAS can be measured with this extent in the studies, which were made on the subject of quality of the increasing demand (Glinia et al., 2004) to animation services. This statement means as a solution to the problem, which Albayrak et al. (2016) stated before, that there was not any scale present to measure the quality of animations in hotels.

Significant effects of animation services on perceived quality and on customer satisfaction indirectly were detected when reviewed both independent from and in comparison 
with the other departments, though not as much. In fact, when conventional departments are reviewed as a whole, importance of animation decreases with the tested scope scoring satisfaction from three separate departments, the effect of the PQAS on the perceived quality of the hotel obtained must not be underestimated. These findings support previous studies that emphasize the importance of animation services. The presentation, quality, and the perception of quality for animation services must always be considered in researches on service quality and customer satisfaction in resort hotels. This matter affects the success conditions of hotel animation that is presented as a new product, which is an answer to increasing competition and the hotel's performance (Albayrak et al., 2016).

The finding about the effects of conventional departments on the perceived quality of the hotel shows consistency to previous studies. It is determined that for hotels, satisfaction with the performance of housekeeping, reception, and food \& beverage shows correlation to customer satisfaction and loyalty (Kandampully \& Suhartanto, 2000). Researchers state that the satisfaction from housekeeping is more effective than the other departments and the price, and link this to, the room being the main presentation for the hotels.

The anticipated result for the relation between the perceived quality of the hotel and the overall satisfaction materialized in an important level for resort hotels. Even in facilities based on the mass production model and where the sensitivity against the customers is not as much as a city hotel, the importance of the customer perception is put forward. Actually, Hung et al. (2010) point out that the prices of resort hotels in Taiwan are much higher than the city hotels and express this fact due to the availability of more leisure amenities and scenic surroundings, which resort hotels offer. Nevertheless, the number of hotels in popular destinations like Antalya and resort tourism to be influenced by the conjuncture left this field of facilities to cheaper options and high competition.

\section{Conclusion and implications}

The effects of animation services were percept enough as it was an area that created offerings for satisfying customer needs in parallel with the customer satisfaction theory. Correspondingly, even though the scale of effect of the animation events to overall hotel satisfaction can be understood, it might not be appreciated enough. This study shows what kind of place animation holds in the overall perception of accommodation. The results may be generalized to the resort hotels from diverse mass tourism regions and especially from the Mediterranean.

The effect of the animation services to quality and satisfaction is essential to these services to be presented actively. That is why it is essential for managers to design a sufficient animation program of high quality; these programs need to be designed properly on grounds of time and place for tourists, the materials that are used to be sufficient and eligible, the crew of animation services to have adequate knowledge, experience, and a manner that is kind and affectionate toward the customers. In this regard, (a) animation should be stressed among the overall hotel presentations and (b) the adequacy of animation services should be provided. In resort hotels, generally, animation services are given to a specific core team, and many activities are being outsourced (Bolat \& Y1lmaz, 2009). This shows that a visual such as the resort hotels does not care about animation services that much. If there is no sufficient number and quality source for animation workers, it is made essential to deal with the issues of features, people relations, entertaining, and channeling talents of the animation personnel. In 
regard to this, these managerial implications should be present based on the conclusions of this study:

1) The managers should put the animation services in the center of marketing activities, putting this forward in design and presentation by focusing animation as well as classic presentations. It seems probable to pass possible competitors with both handling animation as a differentiating element and presenting a high-quality animation. It also seems possible for resort hotels to convert to animation and entertainment hotels.

2) The importance of animation services can lead the hotels to develop the activities of animation. In this occasion, the hotels need to show some effort in activities such as water sports, aerobics, gymnastics, etc., field activities such as football and archery, and recreation events as well as demonstrations. It can be expected that new demonstrations that would draw the attention of target market can emerge.

3) From the top to the bottom, all animation personnel should be educated, supported by rewards such as payments, bonuses, etc., motivated, and their relationships with customers should be strengthened.

4) It is a must for general administrations to follow the subject of creating successful animation programs. The development of animation is too big of a subject to leave it to only the animation department.

5) It would also be informative for the destinations that have ongoing developments about resort hotels to enlighten the influence of animation activities to the satisfaction that the customer gets from the hotel. The satisfaction of the customer and its measurement are crucial criteria on grounds of destination benchmarking and are the subjects that are in correlation. Comparison happens with the research on the best practices in industry and the example of their usage (Fuchs \& Weiermair, 2004). Antalya is a worldwide destination, and the debates on the subjects of variables that affect the satisfaction of customers would present inputs to development of all resort destinations.

In this study, the quality of animation services is handled within a specific scale and comparatively to the other departments. This content keeps out a view that is more extensive and qualitative. This content can be widened with more qualitative researches. The research, being limited to a certain destination, keeps out the possible effects of tourists with different features and different animation services. With destinations that are elected from different countries, many broader conclusions can be reached. It is a probability that can be used to argue the animation services in city hotels and sport hotels, aside from the resort hotels, to which this study focused on.

\section{References}

Albayrak, T., Caber, M., \& Öz, E.K. (2017). Assessing recreational activities' service quality in hotels: An examination of animation and spa \& wellness services. Journal of Quality Assurance in Hospitality \& Tourism, 18(2), 218-234.

APDCT (2015). Statistics. Antalya Provincial Directorate of Culture and Tourism, http://www.antalyakulturturizm.gov.tr/TR,88282/2014-yili.html, Last accessed in August 18, 2016.

Bagozzi, R.P., \& Yi, Y. (1988). On the evaluation of structural equation models. Journal of the Academy of Marketing Science, 16(1), 74-94.

Bolat, T., \& Y1lmaz, O. (2009). The relationship between outsourcing and organizational performance: Is it myth or reality for the hotel sector. International Journal of Contemporary Hospitality 
Management, 21(1), 7-23.

Busacca, B., \& Padula, G. (2005). Understanding the relationship between attribute performance and overall satisfaction: Theory, measurement and implications. Marketing Intelligence \& Planning, 23(6), 543-561.

Caruana, A., Money, A.H., \& Berthon, P.R. (2000). Service quality and satisfaction-the moderating role of value. European Journal of Marketing, 34(11/12), 1338-1353.

Caruana, A. (2002). Service loyalty: The effects of service quality and the mediating role of customer satisfaction, European Journal of Marketing, 36(7/8), 811-828.

Costa, G., Glinia, E., Goudas, M., \& Antoniou, P. (2004). Recreational services in resort hotels: Customer satisfaction aspects. Journal of Sport \& Tourism, 9(2), 117-126.

Cronin, J.J., \& Taylor, S.A. (1992). Measuring service quality: a re-examination and extension. Journal of Marketing, 56, 55-68.

Demir, M., \& Demir, Ş.Ş. (2015). The evaluation of hotel animation services from managers and tourists perspective. International Journal of Social Sciences and Education Research, 1(1), 44-61.

Esposito Vinzi, V., Trinchera, L., \& Amato, S. (2010). PLS path modeling: From foundations to recent developments and open issues for model assessment and improvement, in: V. Esposito Vinzi, W. Chin, J. Henseler \& H. Wang (eds.), Handbook of partial least squares, Springer, 47-82

Fallon, P., \& Schofield, P. (2004). Just trying to keep the customer satisfied. Journal of Quality Assurance in Hospitality \& Tourism, 4(3-4), 77-96.

Fornell, C., \& Larcker, D.F. (1981). Evaluating structural equation models with unobservable variables and measurement error. Journal of Marketing Research, 18(1), 39-50.

Fuchs, M., \& Weiermair, K. (2004). Destination benchmarking: An indicator-system's potential for exploring guest satisfaction. Journal of Travel Research, 42, 212-225.

Glinia, E., Costa, G., \& Drakou, A. (2004). Hotel animation and professional perspectives in Greece. Tourism Today, 4, 123-130.

Hai-yan, K., \& Baum, T. (2006). Skills and work in the hospitality sector: The case of hotel front office employees in China. International Journal of Contemporary Hospitality Management, 18(6), 509-518.

Hulland, J. (1999). Use of partial least squares (PLS) in strategic management research: a review of four recent studies. Strategic Management Journal, 20(2), 195-204.

Hung, W., Shang, J., \& Wang, F. (2010). Pricing determinants in the hotel industry: Quantile regression analysis. International Journal of Hospitality Management, 29(3), 378-384.

Johann, M., \& Anastassova, L. (2014). The perception of tourism product quality and tourist satisfaction: the case of polish tourists visiting Bulgaria. European Journal of Tourism Research, 8, 99-114.

Kandampully, J., \& Suhartanto, D. (2003). The role of customer satisfaction and image in gaining customer loyalty in the hotel industry. Journal of Hospitality and Leisure Marketing, 10(1-2), 3-25.

Kandampully, J., \& Suhartanto, D. (2000). Customer loyalty in the hotel industry: the role of customer satisfaction and image. International Journal of Contemporary Hospitality Management, 12(6), 346351.

Knutson, B.J., Beck, J.A., \& Yen, H.H. (2004). Marketing the mid-price independently owned resort: A case study with implications for managers. Journal of Hospitality \& Leisure Marketing, 11(4), 6579.

MCT (2016). Statistics. Republic of Turkey, Ministry of Culture and Tourism, http://yigm.kulturturizm.gov.tr/TR,9853/istatistikler.html, (accessed in August 18, 2016). 
Mattila, A., \& O'Neill, J.W. (2003). Relationships between hotel room pricing, occupancy, and guest satisfaction: A longitudinal case of a midscale hotel in the United States. Journal of Hospitality \& Tourism Research, 27(3), 328-341.

Meng, F., Tepanon, Y., \& Uysal, M. (2008). Measuring tourist satisfaction by attribute and motivation: The case of a nature-based resort. Journal of Vacation Marketing, 14(1), 41-56.

Mikulic, J., \& Prebezac, D. (2011). Evaluating hotel animation programs at Mediterranean sun-andsea resorts: An impact-asymmetry analysis. Tourism Management, 32(3), 688-696.

Neal, R.M., \& Hinton, G. (1998). A view of the EM algorithm that justifies incremental and other variants. In M. Jordan (Ed.), Learning in graphical models (pp.355-368). Kluwer Academic Publishers.

Noe, F.P., \& Uysal, M. (1997). Evaluation of outdoor recreational settings. A problem of measuring user satisfaction. Journal of Retailing and Consumer Services, 4(4), 223-230.

Oh, H. (1999). Service quality, customer satisfaction, and customer value: A holistic perspective. Hospitality Management, 18, 67-82.

Oliver, R.A. (1980). A cognitive model of the antecedents and consequences of satisfaction decisions. Journal of Marketing Research, 17(4), 460-469.

Parasuraman, A., Zeithaml, V.A., \& Berry, L.L. (1985). A conceptual model of service quality and its implications for further research. Journal of Marketing, 49, 41-50.

Parasuraman, A., Zeithaml, V.A., \& Berry, L.L. (1988). SERVQUAL: A multiple-item scale for measuring consumer perceptions of service quality. Journal of Retailing, 64, 12-40.

Park, J., Kim, H.J., \& McCleary, K.W. (2014). The impact of top management's environmental attitudes on hotel companies' environmental management. Journal of Hospitality \& Tourism Research, 38(1), 95-115.

Petrick, J.F., \& Backman, S.J. (2002). An examination of the construct of perceived value for the prediction of golf travelers' intentions to revisit. Journal of Travel Research, 41, 38-45.

Pizam, A., \& Ellis, T. (1999). Customer satisfaction and its measurement in hospitality enterprises. International Journal of Contemporary Hospitality Management, 11(7), 326-339.

Sivadas, E., \& Baker-Prewitt, J.L. (2000). An examination of the relationship between service quality, customer satisfaction, and store loyalty. International Journal of Retail \& Distribution Management, 28(2), 73-82.

Sotiriadis, M.D. (2014). Management and operational issues of animation services in resort and allinclusive hotels: Evidence from Greece. Mediterranean Journal of Social Sciences, 5(20), 692-698.

Shportko, A. (2012). The effect of animation services on the guests' perception of a hotel and intention to visit it. Unpublished Master of Science Thesis, Purdue University, Department of Hospitality \& Tourism Management, West Lafayette, IN.

Sureshchandar, G.S., Rajendran, C., \& Anantharaman, R.N. (2002). The relationship between service quality and customer satisfaction-a factor specific approach. Journal of Services Marketing, 16(4), 363-379.

Taylor, S., Sharland, A., Cronin, J., \& Bullard, W. (1993). Recreation service quality in the international setting. International Journal of Service Industry Management, 4(4), 68-86.

Uysal, M. (2003). Satisfaction components in outdoor recreation and tourism settings. e-Review of Tourism Research, 1(3), 35-38.

Weiermair, K., \& Fuchs, M. (1999). Measuring tourist judgment on service quality. Annals of Tourism Research, 26(4), 1004-1021.

Wong, K.K. (2013). Partial least squares structural equation modeling (PLS-SEM) techniques using SmartPLS. Marketing Bulletin, 24, 1-32. 
Yuksel, A., \& Yuksel, F. (2001). The expectancy-disconfirmation paradigm: A critique. Journal of Hospitality \& Tourism Research, 25(2), 107-131.

\title{
Acknowledgement
}

This study was supported by a grant from Sakarya University Scientific Research Projects Unit (Project number: 2013-50-02-028).

\section{Oğuz Türkay}

\section{Professor}

Department of Gastronomy and Culinary Arts

Faculty of Tourism

Sakarya University, Turkey

Camicedit Mah. Paşa Sk. No: 16 Sapanca/Sakarya/Turkey

+902642956329

turkay@sakarya.edu.tr

Oguz is a professor and head of the department of recreation management in the Faculty of Tourism at Sakarya University. His research interests include strategic management in tourism, environmental friendly solutions in tourism and destination management.

\author{
Abdulmenaf Korkutata \\ Assistant professor \\ Department of Recreation \\ Faculty of Sport Sciences \\ Çanakkale Onsekiz Mart University, Turkey \\ Terzioğlu Yerleşkesi, Merkez / Çanakkale /Turkey \\ +902862182297 \\ menafk@gmail.com \\ Abdumenaf is an assistant professor in the Faculty of Sport Sciences in Çanakkale Onsekiz \\ Mart University. His research areas are recreational motivations and outdoor sports.
}

\section{Özer Yılmaz}

\section{Assistant professor}

Department of International Trade and Logistic

Faculty of Omer Seyfettin Applied Sciences

Bandırma Onyedi Eylul University, Turkey

Yenimahalle, Şehit Astsubay Mustafa Soner Varlık Caddesi, No:77, 10200,

Bandırma/Balıkesir/Turkey

Tel: +90 266 7170051-52-53

oyilmaz@bandirma.edu.tr

Özer is an Assistant Professor in the Faculty of Omer Seyfettin Applied Sciences at Bandirma Onyedi Eylul University. Dr. Y1lmaz's main research interests are currently on marketing in tourism. 